\title{
Chesterman's Syntactic Strategies in Translating English Passive Voice Construction into Arabic
}

\author{
Rabab Ahmad Mizher \\ English Language \& Literature Department, Balqa Applied University, Jordan
}

Received: 07-04-2016

doi:10.7575/aiac.ijclts.v.4n.3p.32
Accepted: 12-06-2016

Published: 01-07-2016

URL: http://dx.doi.org/10.7575/aiac.ijclts.v.4n.3p.32

\begin{abstract}
Contrastive analysis studies occupy a vital role in the course of translation studies. Similarities and differences between systems of languages facilitate the process of learning a foreign/second language along with translating from one language into another. Thus, this study seeks to shed light on strategies employed by EFL learners in translating English passive voice construction into Arabic. More specifically, it investigated these strategies against the syntactic strategies that are proposed by Andrew Chesterman in his book Memes of Translation. Participants from six Jordanian universities (Public and Private) who were studying general translation courses were administered to a translation test of five English sentences that contain both agentive and agentless passive constructions in which participants were asked to translate them into Arabic. The results reveal that participants use the following strategies when translating agentive passive sentences: maintaining passive, topicalization, periphrastic structure and activization. However, when translating agentless passive sentences, participants use the following strategies: maintaining passive, periphrastic structure, lexicalization and activization. These strategies correspond to Chesterman's syntactic strategies: literal translation strategy, transposition, clause structure change and sentence structure change.
\end{abstract}

Keywords: Chesterman, Memes of Translation, English-Arabic Translation Strategies, Syntactic Strategies, Passive Voice, Contrastive Analysis (CA)

\section{Introduction}

The connection between translation and contrastive analysis studies is well-established. Basically, contrastive analysis (CA) is "a hybrid linguistic enterprise that aimed at producing two-valued inverted typologies (a CA is always concerned with a pair of languages) and founded on the assumption that languages can be compared" (James,1980:3). Generally, James (1980) and Fisiak (1981) revealed three broad objectives of contrastive studies; firstly, stating similarities and differences between languages to the aim of reaching universals of languages; secondly, giving insights and implications to second or foreign language teaching and learning and assisting in predicting, diagnosing and scaling difficulties and errors.

Consequently, the second objective leads to the transfer of elements which are isomorphic and have the same semantic and syntactic features, to the analysis of mistakes that are already made by learners and related to the first language negative transfer (interference) and to the prediction of mistakes that might be made by the second language learner due to the differences between L1 and L2. The third objective provides implications and insights to translators, theory of translation and equivalence.

The relationship between contrastive analysis and translation is bidirectional. On one hand, translation theory is regarded as a branch of contrastive linguistics where "translation problems become a matter of the non-correspondence of certain formal categories in different languages" (Hatim and Mason, 1990: 26) and as a result, translated materials provide a rich corpus for contrastive analysis (Kirkwood, 1966). On the other hand, contrastive analysis studies facilitate the process of learning and teaching translation by predicting and diagnosing difficulties and errors (Baker, 1992 and Hatim and Mason, 1990) and the product by judging its quality. Finally, Chesterman (2000) discussed the relevance of contrastive analysis to translation theory with regard to translator' competence and revealed that

[T] he translator needs to know the relevance of each possible choice to his/her intentions, in order to be able to decide on an optimal version. This weighing up of the relative relevancies of different options relies heavily on contrastive analysis, on the translator's knowledge of differences and similarities between the two languages....[which is] an essential part of translator's competence. (p. 80).

\subsection{Aims and Scope}

This study attempts to explore the strategies utilized by undergraduate EFL students in translating English passive voice construction into Arabic by analyzing their responses to an English Arabic translation test that encompasses passive voice construction. Then, participants' strategies are examined against Chesterman's syntactic strategies. Consequently its scope is limited to the aspects of passive voice under investigation that are restricted to those observed in the translation test. The translation test consisted of five sentences administered to the students of selected classes of six 
Jordanian universities in which students were allowed to use dictionaries and suggested English Arabic equivalents of key words were provided on the test papers.

Moreover, the results of the study were limited to the comprehensible answers provided by the students as refereed by a jury. The jury consisted of three Arabic Language and Literature PhD holders of minimum 10 years experience in teaching Arabic language and literature at the university level in addition to four English linguistics and translation professors and associate professors of minimum 15 years experience in teaching translation and linguistics at the universities of Jordan. However, students' wrong answers were not investigated as error analysis is beyond the scope of this study.

\subsection{Chesterman's Syntactic Strategies}

Chesterman (2000) discussed the 'terminological confusion' of translation strategy such as methods, rules, plans, tactics, procedures, principles, etc and established analogy between language learning strategies and communication strategies, on the one hand, and translation learning strategies on the other one, in the sense that in both cases there are kinds of problems to be solved. Communication strategies are ways of solving communication problems that could be reduction strategies (reducing the message in some way) and achievement strategies (attempts to preserve the message but change the means, such as paraphrase or restructuring). Accordingly, translators are "people who specialize in solving particular kinds of communication problems" (p.87).

Chesterman, then, differentiated between comprehension strategies and production strategies. Comprehension strategies "have to do with the analysis of the source text and the whole nature of translation commission; they are inferencing strategies, and they are temporally primary in the translation process" (p.92). Production strategies are "the results of various comprehension strategies: they have to do with how the translator manipulates the linguistic material in order to produce an appropriate target text" (p.92). In this case, production strategies are linguistic ones while comprehension strategies are cognitive ones.

According to Chesterman, strategies are identified as operating in the space between the source text and the target text. He elaborated that 'if you [as a translator] are not satisfied with the target version that comes immediately to mind because it seems ungrammatical, or semantically odd, or pragmatically weak or whatever - then change something in it" (p. 92). Moreover the idea of being "not satisfied" is an indicator of a translation problem. Traditionally, for a translator to "change something" is a concept that has a number of classifications in the works of "Vinay and Darbelnet (1958), Catford (1965), Nida (1964), Malone (1988) and Leuven-Zwart (1989/1990)" (Chesterman, 2000:92-93), like change of order, omission, and change of structure. But Chesterman's proposed strategies are rather flexible and openended. They include three primary groups: syntactic/grammatical strategies $(\mathrm{G})$, semantic strategies (S) and pragmatic strategies (PR). These strategies may also overlap; i.e. pragmatic strategies could include syntactic and semantic strategies.

For the purposes of the current study, only some syntactic/grammatical strategies of Chesterman's are highlighted. These syntactic strategies purely involve syntactic changes of one kind or another and they primarily manipulate form. These are:

1. Literal Translation: It is defined as maximally close to the source language (SL) form, but nevertheless it is grammatical and known to have "the status of a default value" (p.94).

2. Transposition: It means any change of word class, e.g. from noun to verb and adjective to adverb.

3. Phrase Structure Change: It comprises a number of changes at the level of the phrase, including number, definiteness, modification in the noun phrase, and person, tense and mood of the verb phrase.

4. Clause Structure Change: It includes changes that occur in the structure of the clause in terms of its constituent phrases; i.e. active vs. passive, finite vs. non-finite, transitive vs. intransitive.

\subsection{Research Questions}

This study aimed at answering the following questions:

1. What are the strategies used by undergraduate Jordanian Universities' EFL students in translating English passive voice into Arabic?

2. What are Chesterman's syntactic strategies that correspond to the translation of the passive constructions strategies?

\section{Literature Review}

There were many studies that were conducted on translation of English passive voice into Arabic due to difficulties students face. The source of difficulty emerges from the different use of passive in English as compared to Arabic. Khalil (1993) examined the problems of translating English agentive passive into Arabic. His study was "motivated by the findings of contrastive analysis of the passive voice in Classical Arabic and English (Khalil, 1993:169). The participants of the study included two groups: (1) Arab translators who were eight Arabic speaking EFL instructors and twenty-four EFL college students; (2) Nineteen experts who were instructors of the Arabic language and literature at the university level (twelve in linguistics and seven in literature). The purposes of the study were:

(1) to validate our predictions regarding the problem of Arabic translation of English passive sentences, that is, to find out if Arabic instructors transpose the English agentive passive into the Arabic active or use an Arabic passive with an agentive phrase; (2) to elicit Arab experts' 
acceptability judgments on the Arabic translated sentences; and (3) to check the basis of these

judgments, that is, to validate them. (p.170).

Arab translators (students and instructors) were supposed to translate twenty-five English agentive sentences into Arabic and the experts responded to an acceptability judgment questionnaire that includes bio-data and ten Arabic sentences with agentive phrases which were basically selected from the responses to the translation test. They were supposed to decide whether each translated sentence is in Modern Standard Arabic (language of media and modern literature) or Classical Arabic (language of the Glorious Qur'an, the prophetic tradition and ancient literature), then to provide a classical version for the one that is judged to be modern.

The findings revealed that English agentive passive sentences were rather problematic to the translators and controversial to the experts. "The translators [students and instructors] [vacillated] between transposition and literal translation"(p.172). Khalil (1993) attributed that division to the probable occurrence of two factors: Modern Standard Arabic tolerance to the use of passive with agentive phrases and the misconception that this educated variety of Arabic is not different form Classical Arabic. As for experts, the picture was rather blurred since partial disagreement has been detected. "The fact that the experts were divided on the acceptability of some of translated sentences may explain the rarity, even non-existence of acceptability studies in Arabic linguistic research"(p.178).

Accordingly, Khalil judged the "classicalness" of translated sentences against classical Arabic texts. Texts from the Glorious Qur'an, al-Hadith (prophetic tradition and sayings) and Kalam al-Arab (the speech of the Arabs) were surveyed to identify the occurrences of the agentive passive. In the Glorious Quran, two types of agentive phrases were

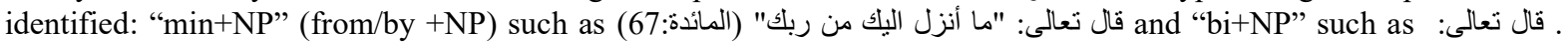
"ولعنو ا بما قالو" (المائدة:64)

Searching al-Hadith (prophetic tradition) only one type of agentive phrase was identified: "bi + NP" and finally searching the speech of the Arabs (the seven odes, ancient proverbs, a collection of Arab speeches) revealed the use of two types of agentive passive, "bi+NP" and "min +NP". However, searching the ancient Arabic dictionaries divulged the occurrence of the prepositional phrase "min qibali" in active sentences which "exclude it from the types of agentive [passive] phrases accepted by CA [Classical Arabic]" (Khalil, 1993: 176). As a result, two agentive passive phrases are acceptable by Classical Arabic "bi+NP" and "min +NP", such "observations have shed some light on the time-honored claim about the "agentlessness' of the passive construction in Arabic" (p.179)

Mohawesh (2004) studied problems of translating agentive and agentless passive voice in English, French and Arabic and found out that students force the source text structure into the target text without paying much attention to linguistic rules. English has two passive constructions: agentive and agentless, Arab students find difficulty because Arabic has only agentless passive construction. The researcher administered twenty-five English passive sentences that cover all types of passive to twenty-five fourth-year B.A. students in the Department of English Language and Literature at Yarmouk University.

The findings revealed low performance with regard to translation of English passive into Arabic with $26.4 \%$ of correct translation category. The researcher analyzed the strategies used by students in translating and concluded that students used four strategies: passive, active, nominalization and adjectival strategies. The highest percentages were in keeping the English passive into Arabic passive with $63.4 \%$ of total strategies where students used the forms as من من and خلال for the English by-phrase and considered by the researcher as "non indigenous construction imposed on the Arabic language by the influence of western languages especially English and French" (Mohawesh, 2004: 33). Another problematic area to the students was translating the English present passive into Arabic past passive. The findings of the study also revealed that translating agentless English passive into Arabic is not problematic to the students and word for word translation was inadequate for translating the English passive into Arabic. Mohawesh (2004) recommended that students "need to improve their structural competence in English and Arabic through extensive training in the use of the passive voice if 'naturalness' and 'adequacy' in the translation of passive are sought' (p.54).

Al-Raba'a (2013) studied the structural borrowing from English into Arabic in translation. He investigated the employment of the English passive voice translation into Arabic passive sentences. He administered the participants of the study (Eleven Arabic English bilinguals who live in the USA and twenty native speakers of Arabic learning English as a foreign language) to ten English sentences; five of them are passive while the other five are active for distraction. The analysis of the two groups' data revealed that 'sixty-four percent of the bilinguals, on the one hand, translated the English passive sentences into Arabic active sentences, whereas thirty-five percent of the monolinguals did so’ (p. 211). However, the analysis also revealed that ' [o]nly did thirty-six percent of the former... keep the sentences in the passive after translating them into Arabic whereas sixty-five percent of the latter did so' (p. 211) which implies that the bilinguals are less influenced by the English passive due to their advanced linguistic ability. The researcher concluded that 'the Arabic speaking monolinguals learning English as a foreign language are much more involved in the grammaticalization process than the Arabic-English bilinguals' (216), i.e. to extend the function of the by-phrase to pattern replication of English passives.

\section{Method of the Study}

\subsection{Tool of the study: Translation Test}

It is the main tool of the study that was designed to detect strategies used by students in translating passive voice constructions. It consisted of five English sentences of various lengths totaling 181 words . These sentences reflected 
certain aspects of agentive and agentless passive voice that were chosen in line with students discussed texts during the classes and their official exam texts.

These sentences were extracted from various websites like Jordanian English newspapers and BBC English website. They reflected social, cultural, academic, educational relevant areas to students' environment. In order to control the new words variable, the students were allowed to use dictionaries and key words with suggested equivalent in Arabic were provided on the test papers so as they focus on syntactic constructions. The amount of time allotted to the test was 50 minutes.

\subsection{Validity and Reliability of the Translation Test}

The translation test was validated by five Jordanian and Iraqi specialists' professors who are specialized in applied linguistics and translation and are teaching at both graduate and undergraduate levels in the English Department and Translation Department at the University of Jordan, Yarmouk University and Applied Science Private University. Their remarks were considered. A suggested translation of the translation test was also judged by the above mentioned professors in addition to two Arabic PhD holders of at least ten years of experience in teaching the Arabic language at the university level and their remarks were considered as well. As for reliability, the test was piloted twice to a limited number of students at two of the universities under investigation then it was modified accordingly; i.e. the number of sentences was reduced to five instead of ten. The test was administered to the participants at the six universities.

\subsection{Stages of the Study}

\subsubsection{Exploratory Stage}

The researcher visited the universities and constructed unstructured field observation to explore how translation instructors present and tackle the translation of the passive voice construction

\subsubsection{Main Stage}

The researcher administered a translation test to the students' participants upon agreeing on a specific day and time with instructors. Students were to translate English sentences into Arabic. The sources of the content of the translation test were derived from the exploratory stage, literature of contrastive studies and the researcher experience repertoire.

\subsection{Data Analysis}

The analysis of the translation test was the cornerstone of the whole study and the process the researcher followed was a developed one. Basically, the researcher considered students' correct/acceptable translations as loaded and rich corpus. Such an idea paved the way for regarding the current study as a corpus-based study. Upgrading students' responses to this level was much of thinking reasonably of our students potentials since they are a reflection of future translators or at least users of the Arabic Language.

Students' various responses were vital point to be considered. It was not always practical to assess their translations in comparison with one standard translation following the motto of most translators' instructors who always keep saying there is no one final/ideal/standard, etc, translation. Different versions were permissible; the judgment of their acceptability and/or grammaticality ought to be approved by professional translators and/or Arabic language professors. Consequently, the researcher developed a content sheet that included all responses for each sentence with regard to the investigated syntactic constructions. The content sheet that included all responses was validated by Arabic language professors and translation professors to judge their acceptability and/or grammaticality. Attempts to develop the content analysis sheet was achieved almost $97 \%$ of consistency for inter-rater reliability between the researcher and a colleague who has M.A in translation and experience in teaching translation and other courses for more than ten years.

Students' translations were assessed in comparison with the suggested standard translation, on the one hand, and content sheet grammatical and/or acceptable responses, on the other one. Each sentence was rated on a four-level score based on failure, incomprehensible, comprehensible and correct translation (Al-Abed Al-Haq and Ahmad, 1995). However, for statistical purposes the rating was reduced to two levels: firstly, unacceptable score which included failure to translate and incomprehensible translation and secondly, the acceptable score which included the comprehensible translation and correct translation. Finally, the researcher approached translation test data analysis by calculating percentages per strategy.

\section{Findings of the Study}

In its broader sense, the present study aimed at bridging the gap between translation theoretical aspects and actual translation practices. Accordingly, it assumed that students' awareness of passive voice constructions differences in both English and Arabic enable them to manipulate these constructions so as to come up with the final correct product. In precise, it intends to detect strategies employed by Jordanian EFL university students in translating passive.

\subsection{Findings Related to the First Question}

The first question is "What are the strategies used by undergraduate Jordanian Universities' EFL students in translating certain aspects of English passive voice into Arabic? To answer the question, the strategies were stated and its frequencies were calculated. The strategies were: 
4.1.1 Strategies employed by Jordanian EFL students in translating agentive passive voice:

Students used two main types of strategies; they either kept the English agentive passive into Arabic agentive passive (they added the agent) or simply they followed what is called "passive void" strategies; i.e. they tend to use strategies to avoid using the agentive passive.

Table 1 presents frequencies and percentages of students' strategies in translating English agentive passive sentences into Arabic. Frequencies and percentages were classified according to the item/sentence.

Table 1. Frequencies and percentages of agentive passive strategies occurrences in students' translation test acceptable responses

\begin{tabular}{|c|c|c|c|c|c|}
\hline \multirow{2}{*}{$\begin{array}{c}\text { Syntactic } \\
\text { Construction }\end{array}$} & \multirow[t]{2}{*}{ Strategy } & & Sentence & Sentence & Sentence \\
\hline & & & 2 & 3 & 4 \\
\hline \multirow{10}{*}{$\begin{array}{l}\text { Agentive } \\
\text { Passive } \\
\text { Voice }\end{array}$} & \multirow{4}{*}{$\begin{array}{l}\text { Maintaining } \\
\text { Passive verb }\end{array}$} & Frequency & 35 & 33 & 126 \\
\hline & & Percentage & 23.97 & 22.30 & 67.74 \\
\hline & & Frequency & 65 & 8 & 2 \\
\hline & & Percentage & 44.52 & 5.41 & 1.08 \\
\hline & \multirow[t]{2}{*}{ Topicalization } & Frequency & 13 & 92 & 31 \\
\hline & & Percentage & 8.90 & 62.16 & 16.67 \\
\hline & \multirow{2}{*}{$\begin{array}{l}\text { Periphrastic } \\
\text { Structure }\end{array}$} & Frequency & 0 & 0 & 23 \\
\hline & & Percentage & 0.00 & 0.00 & 12.37 \\
\hline & \multirow[t]{2}{*}{ Activization } & Frequency & 8 & 9 & 4 \\
\hline & & Percentage & 5.47 & 6.09 & 2.15 \\
\hline \multirow{2}{*}{\multicolumn{2}{|c|}{$\begin{array}{l}\text { Total Number of Students } \\
\text { who Provided Acceptable } \\
\text { Translation to each Sentence }\end{array}$}} & Frequency & 146 & 148 & 186 \\
\hline & & Percentage & 100 & 100 & 100 \\
\hline
\end{tabular}

Table 1 shows that the first strategy is classified into two sub-strategies according to by-phrase translation; the researcher differentiated between translations like من قبل/عن طريق/ من خلال ...الخ , one the hand, and s on the other one. Then each is followed by the total number of students who provided acceptable answers per each sentence. The following are the strategies in detail:

\subsubsection{Maintaining Passive}

Students translated the English agentive passive into Arabic passive in addition to the agent; so they kept the same word order of passive construction and translated the by-phrase by words like:

$$
\text { من قبل/ من/ من خلال/بوساطة/ عن طريق/على يد }
$$

Examples:

\begin{tabular}{|c|c|}
\hline English & Arabic \\
\hline $\begin{array}{l}\text { 1. Season of wildfires caused by negligent } \\
\text { picnickers kicked off despite authorizes calls... }\end{array}$ & 1 1ـبدأ موسم حر ائق الغابات المُسبب من قبل/الذي سبَبب \\
\hline $\begin{array}{l}\text { 2. The Educational Fund which was set up } \\
\text { recently by Ministry of Education began } \\
\text { operation on Saturday }\end{array}$ & 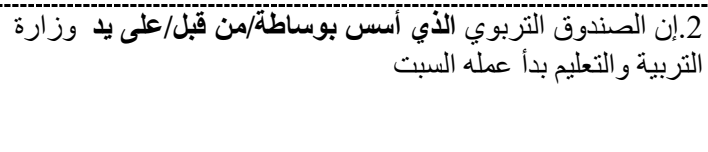 \\
\hline
\end{tabular}

\subsubsection{Passive Void Strategies}

This strategy takes more than one form. Students used the active verb instead of the passive one and then made different transformatios to the structure. These transformations are:

a. Topicalization: It refers to the syntactic transformation that fronts the direct object or the indirect object to the sentence initial position. In Arabic, the topicalized object receives the nominative case. Students utilized this strategy to overcome the almost non-existence of agentive passive in Arabic. Then they either kept the by-clause in Arabic but in active voice structures or used inflected verbs such as الذي كان سببه / الذي أسسته 
Examples:

\begin{tabular}{|c|c|}
\hline English & Arabic \\
\hline $\begin{array}{l}\text { 1. Season of wildfires caused by negligent } \\
\text { picnickers kicked off despite authorizes calls... }\end{array}$ & 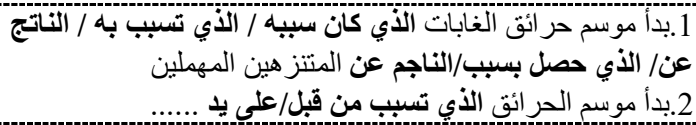 \\
\hline $\begin{array}{l}\text { 2. The Educational Fund which was set up } \\
\text { recently by Ministry of Education began } \\
\text { operation on Saturday }\end{array}$ & 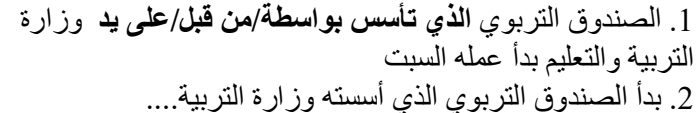 \\
\hline
\end{tabular}

b. Transferring into periphrastic structure and topicalization: A periphrasis is a device by which grammatical meaning is expressed by one or more free morphemes. Accordingly, periphrastic transformation of English passive is achieved by adding verbs like: تم/ينت/سين/قام/يقوم and changing the main English passive verb into Arabic verbal noun (Shabanah, 1981:295, Al-Najjar, 2007:182, and Khalil, 2010:273), as a result, topicalization is also achieved. However, students may also keep the by-clause.

Examples:

\begin{tabular}{|c|c|}
\hline English & Arabic \\
\hline $\begin{array}{l}\text { 2. The Educational Fund which was set up } \\
\text { recently by The Ministry of Education began } \\
\text { operation on Saturday }\end{array}$ & 2. عمله السبت الصندوق التزبوي الذي قامت بتأسيسه وزارة التربية والتعليم بدأ \\
\hline
\end{tabular}

c. Activization: This strategy is within the domain of students' resort to the active verb. But in this case students make drastic changes to the sentence since they change the whole passive voice into active voice.

Examples:

\begin{tabular}{|c|c|}
\hline English & Arabic \\
\hline $\begin{array}{l}\text { 1. Season of wildfires caused by negligent } \\
\text { picnickers kicked off despite authorizes calls... }\end{array}$ & 2.وسبب المتنز هين المهملين موسم حر ائق الغابات................ \\
\hline $\begin{array}{l}\text { 2. The Educational Fund which was set up } \\
\text { recently by The Ministry of Education began } \\
\text { operation on Saturday }\end{array}$ & 1.أسبت .... وزراة التربية والتعليم الصندوق التربوي الذي بدأ عمله يوم \\
\hline
\end{tabular}

4.1.2 Strategies employed by Jordanian EFL students in translating English agentless passive voice into Arabic

Identical to agentive passive voice translation strategies, students either kept the passive verb in Arabic, or transferred it into active verb in Arabic by using "passive void" strategies. Nevertheless, this time is different since agentless passive does exist in Arabic in uncontroversial manner.

Table 2 presents frequencies and percentages of students' strategies in translating English agentless passive sentences into Arabic. Frequencies and percentages are classified according to the item/sentence. Then each sentence is followed by the total number of students who provided acceptable answers for each sentence.

Table 2. Frequencies and percentages of agentless passive strategies occurrences in students' translation test acceptable responses

\begin{tabular}{cccccc}
\hline \multirow{2}{*}{$\begin{array}{c}\text { Syntactic } \\
\text { Construction }\end{array}$} & \multicolumn{2}{c}{ Strategy } & $\begin{array}{c}\text { Sentence } \\
1\end{array}$ & $\begin{array}{c}\text { Sentence } \\
2\end{array}$ & $\begin{array}{c}\text { Sentence } \\
5\end{array}$ \\
\hline \multirow{2}{*}{$\begin{array}{c}\text { Agentless } \\
\text { Passive } \\
\text { Voice }\end{array}$} & $\begin{array}{c}\text { Maintaining } \\
\text { Passive verb }\end{array}$ & Frequency & 134 & 66 & 0 \\
\cline { 2 - 5 } & $\begin{array}{c}\text { Periphrastic } \\
\text { Structure }\end{array}$ & Percentage & 69.79 & 45.21 & 0.00 \\
\cline { 2 - 5 } & Lexicalization & Percentage & 5.21 & 5.48 & 0 \\
\cline { 2 - 5 } & Activization & Frequency & 136 & 3 & 104 \\
\cline { 2 - 5 } & Percentage & 70.83 & 2.05 & 70.28 \\
\cline { 2 - 5 } & Percentage & 9.38 & 19 & 0 \\
\hline \multirow{2}{*}{$\begin{array}{c}\text { Total Number of Students who } \\
\text { Provided Acceptable }\end{array}$} & Frequency & 192 & 146 & 148 \\
\cline { 2 - 5 } Translation to each Sentence & Percentage & 100 & 100 & 100 \\
\hline
\end{tabular}


Table 2 shows that the first sentence contains more than one English agentless passive construction. Therefore, there is no congruence between total number of students' acceptable answers and total number of strategies in the first sentence. Moreover, there are responses that are considered incorrect at the construction level but they did not affect the acceptability of the whole sentence as in sentence number 5. The following are the strategies in detail:

\subsubsection{Maintaining Passive}

Students translated the English agentless passive into Arabic passive construction.

Examples:

\begin{tabular}{|c|c|}
\hline English & Arabic \\
\hline 1. Water shortage cannot be solved... & 1. مشكلة نقص المياه لا يمكن ان تحل.... \\
\hline 2. An Ambitious campaign designed to raise.... & 2. حملة طموحة مُصممة/صَممت لزيادة الوعي.... \\
\hline 3. Established in memory of her majest.., Tkiyyat & 3.أسست تكية ام علي في ذكرى وفاة الملكة علياء..... \\
\hline
\end{tabular}

\subsubsection{Passive Void Strategies}

This strategy takes more than one form. Students used the active verb instead of the passive one and then made different transformations to the structure. These transformations are:

a. Transferring into periphrastic structure: It is achieved by adding words like تم /قام to the verb and change that verb into a verbal noun

Examples:

\begin{tabular}{|c|c|}
\hline English & Arabic \\
\hline 1. Water shortage cannot be solved... & 1. لن يتم حل مشكلة نقص المياه .... \\
\hline 2. An Ambitious campaign designed to raise.... & 2. تم تصميم حملة طموحة لزيادة الوعي.... \\
\hline 3. Established in memory of her majesty., Tkiyyat & 3.تم تأَسيس تكية ام علي في ذكرى وفاة الملكة علياء.... \\
\hline
\end{tabular}

b. Lexicalization: Students tend to either change the English passive verb into an Arabic verbal noun/active verb or replace the whole passive verb with another contextually appropriate active verb.

Examples:

\begin{tabular}{|c|c|}
\hline English & Arabic \\
\hline 1. Water shortage cannot be solved... & 1. آن مشكلة نقص المياه في الاردن لا يمكن حلها .... \\
\hline 2. An Ambitious campaign designed to raise.... & 2. حملة مياه طعوحة تهدف اللى/تسعى الىى/تعمل على زيادة ..... \\
\hline 3. Established in memory of her majest.., Tkiyyat & 3.تأسست تكية ام علي في ذكرى وفاة الملكة علياء............... \\
\hline
\end{tabular}

c. Activization: Students tend to change the whole passive voice into active voice and add the deleted understood agent Example:

\begin{tabular}{|c|c|}
\hline English & Arabic \\
\hline 1. Water shortage cannot be solved... & 1.لن تسنطيع الحكومة حل مشكلة نقص المياه .... \\
\hline
\end{tabular}

\section{Discussion}

Emphasizing the inseparable relationship between syntax and translatability, underscoring the central role of learnertranslator who is equipped with strategies in the learning process, the quotation below provides a concise and condensed description that noticeably reflects the aims of this study. These aims magnify the following: the learner-translator's role in the translation learning process, the syntactic theoretical knowledge of both languages and the significance of strategies in the translation process.

Psychologists have told us that individuals acting alone do not normally cause too much trouble; it is only when they form into crowds that they become unmanageable. Similarly, individual lexical items, be they armed with polysemy and shared exponence, can only stage sporadic strikes; it is when they group into long syntactic stretches that they begin really to launch all-out assaults on the translator. In the past decades, strategy has become a buzzword; it has been used, perhaps too often, in discussions, papers, and books about translation. In view of the close relationship between syntax and translatability, strategy would mean very little if attention were paid only to individual lexical items, not to aspects of syntax; for this would, to sustain the military metaphor, be tantamount to training a rifle on individual troops without looking at entire battle formation (Wong 2006:130). 
5.1. Discussion of the Findings Related to the First Question

The findings of the first question deal with the strategies employed by Jordanian Universities' EFL learners in translating passive voice. These strategies were elicited by administering Jordanian universities' EFL students to a translation test that mirrors certain aspects of passive voice constructions. Below is a detailed discussion of these findings.

\subsubsection{Strategies related to the translation of English agentive passive into Arabic}

The translation of English agentive passive constructions is rather problematic to Arab learners (Al-Abed Al-Haq and Ahmad, 1995, Aziz, 1989, El-Haj Ahmad, 2009, Khalil, 1993 and Mohawesh, 2004,) and controversial to the experts (Al-Najjar, 2007, Aziz ,1989, Khalil, 1993, and Nofal, 1993). Students' translations were simply an obvious manifestation of such dilemma. In general, voice "conveys information on the topical focus of the sentence" (Ryding, 2005:657), so, in Arabic, the verb is either active (the doer of the action is the subject of the verb) or passive the direct object of the verb becomes the subject.

Just like most of Arab researchers, Aziz (1989) stated that the agent of Arabic active sentence is omitted in passive sentences and "the passive in Arabic is agentless" (p.267), therefore, English agentive passive sentences are translated into Arabic active sentences, e.g. "The thief was caught by the police" is translated as "قبضت الثرطة على اللص If the theme is considered, there are two possible translations: " Another possibility is "This city was built by the Abbasid Caliph, Harun Al-Rashid" is translated into

" Aziz (1989) also stated other forms in Arabic that have a passive sense and

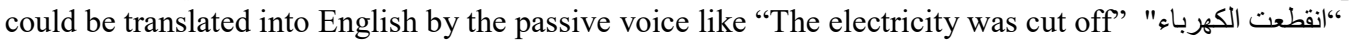

Ryding (2005:657) discussed the Arabic passive meaning contrasted with Arabic active meaning from western grammatical terms of 'voice'. Compared with the English passive, there are two ways to express passive in Arabic. The first one is inflectional passive that is achieved by shift of vowel pattern within the verb: e.g. 'uqid-a' عُقِ 'it was held' from 'aqad-a' عََ 'he held' and the second one is derivational passive: e.g. in'aqad-a il 'it was held' and it reflects a resultative state of the object (fataH-tu 1-baab-a fa-nfataH-a ) فتحت الباب فانفتح 'I opened the door and it opened . The first type of the passive is known in Arabic as al-majhuul which indicates that the agent or the doer of the action is not mentioned in the sentence and "this contrasts with English where one may readily mention the agent in passive construction through the use of preposition 'by' (The problem was studied by us" (p.658), while the second type is known as muTaawi 'مطاو ع' "obedient”" to an action that has occurred.

The existence of Arabic constructions like من قِبل as a translation to the English by-phrase is rather problematic. Considering a descriptive point of view, most researchers agree that such a translation is used and it is a reflection of the media. Few of these researchers emphasize the idea that agentive passive sentences in Arabic do not normally exist (AlNajjar, 2007, Aziz, 1989, Khalil, 1993 and 2010, Alkhuli, 1999 and Shaheen, 1998). Moreover, Khalil (1993) traced the existence of Arabic agentive passive sentences by conducting a corpus-based study to finally reveal that "من قبل construction is used as analogy to the construction of "من لدن" which is mentioned twice in passive sentences in the Glorious Quran .

As a result, some translators tend to translate the English agentive passive into Arabic agentive passive resorting to the existence of agentive passive sentences in the Glorious Quran, flexibility of the Arabic language in terms of word order (Aziz, 1989) and impact of translation in the media (Al-Najjar, 2007 and Aziz, 1989).

Others totally disagree with the idea that agentive passive construction exists in Arabic elaborating that "من قبل translation to the by-phrase construction appeared in active sentences not passive, despite the existence of certain agentive passive sentences in the Glorious Quran where words like sire used for the translation of the by-phrase construction; however, it was derived from ill-formed construction (Al-Najjar, 2007) assuming that the active sentence pattern is V-S-DO-IO. Such controversial issue particularly among Arabic grammarians and experts in addition to overwhelming use of Arabic agentive passive sentences or transformation of Arabic active sentences into agentive passive in media have swollen the gap between theoretical knowledge of Arabic rules and their functions, on the one hand, and the practical use of language, on the other, in translation and in ordinary use of language.

Considering the optional transformations that operate on well-formed structures to derive well-formed structures and produce among others English agentive passive for functional and stylistic purposes (Al-Najjar, 2007), Arabic opts for using other optional transformations to keep the end-weight or end-focus of the English agentive passive. Arabic optional transformation rules involve processes like topicalization by utilizing Arabic enclictic/proclictic/pro-enclictic and is achieved by fronting the direct object or indirect object to sentence initial position, for example, the passive

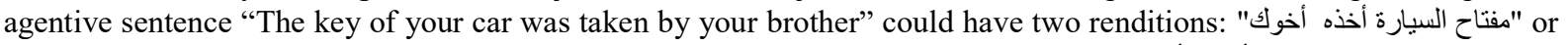
transforming the whole agentive passive voice into Arabic active voice like: "أخوك أخذ مفتاح السيارة" (Al-Najjar, 2007).

As stated above, students' translations are apparent demonstrations of researchers and experts tentative discrepancy over Arabic agentive passive. The variety of their translations to the same construction is twofold. On the one hand, it mirrors the flexibility and adaptability of Arabic due to relatively free word order; on the other, it mirrors diversity of researchers and experts interpretations and differences that enrich Arabic in the world of globalization. In what follows, a discussion of students' strategies pertaining to the translation of English agentive passive constructions into Arabic is presented according to the strategy. Students use four main strategies in compliance with content of sentences in the translation test and with the analytical approach adopted by the researcher. 
5.1.1.1 Maintaining Passive

Students translated the English agentive passive into Arabic passive in addition to the agent; so they kept the same word order of passive construction and translated the by-phrase by words like:

$$
\text { بوساطة / عن طريق/ على يد / من قبل / من / من خلال ... الخ }
$$

Referring to Table 1, agentive passive construction has appeared in sentences two, three and four. Table 1 classifies this strategy into two sub-strategies according to contrastive analysis studies that are related to the translation of the English by-phrase into Arabic; the first sub-strategy is the use of the above mentioned renditions save for "من". The second sub-strategy is the students' use of "من" as a translation to the English by-phrase which -according to some scholars and researchers- is rather acceptable (Alkhuli, 1999, Khalil, 1993 and Shabanah, 1981). Shabanah (p.110) stated certain restrictions on the use of 2 to the translation of English by-phrase that should be followed by a real doer and should be transformed from well-formed active sentence. Al-Najjar (2007:210) stated that the Arabic agentive passive construction which is mentioned in the Glorious Quran is derived from an ill-formed sentence which contradicts the formation of the agentive passive and it should be transformed from a well-formed active voice sentence. Consider the following:

$$
\text { 2. 1. قال تعالى: "و ما أوتي النبيون من ربهم." (البقرة: 136) }
$$

The second active sentence is ill-formed.

The first point to be considered here is the criterion of judgment: Is it the grammaticalness of the construction or its acceptability? Upon reviewing part of related literature and considering the remarks of Arabic professors' jury, the translation of English agentive passive into Arabic agentive passive is used and rather acceptable. In contrast, upon reviewing other part of related literature and the remarks of most Arab English professors of linguistics and translation jury; the translation of English agentive passive into Arabic agentive passive is to a certain extent unacceptable. Considering traditional Arab grammarians remarks, both parties almost agreed that the existence of Arabic agentive passive is to - a certain extent - "a novelty" due to the rarity of Arabic passive compared with Arabic active in general (Al-Najjar, 2007, Aziz, 1989, Khalil, 1993, Nofal, 1993, Shaheen, 1998, Shawqi, 1991) and complexity of transformational rules in forming passive from different verb forms (verb III, verb IV, verb V...etc) (Shawqi, 1991).

Table1 revealed that almost $68 \%$ of students used this strategy for the second sentence, $41 \%$ for the third sentence and $69 \%$ for the fourth sentence. Considering the passive in each sentence, these percentages are the highest among other strategies. These results correspond to Mohawesh (2004) results that students force the source text structure on the target text without considering target text (TT) linguistic rules. The highest percentage was in maintaining the English agentive passive into Arabic passive plus the by-phrase of $63.4 \%$ of total strategies. Students also used forms like and من خلال by the influence of western languages especially French and English.

On the other hand, these results contradict with El Haj Ahmed's (2009) results that students may keep the Arabic passive plus an agentive phrase (by-phrase) because the percentage of students using this strategy was only 2.1. El Haj Ahmad (2009) attributed students' use of this strategy to students' lack of awareness of the passive system in English and Arabic (p.142) and added that such a construction "weaken their Arabic style" since there is no agentive passive in Arabic. Such a tendency among students reflects the overwhelming use of Arabic agentive passive in the mass media which is according to the researcher's opinion and many other scholars as Al-Najjar (2007), Aziz (1989), Farghal and Shunnaq (2011), Khalil (1993), Nofal (1993) and Shawqi (1991) a novelty and thus acceptable in translation.

\subsubsection{Topicalization}

Students' assumed awareness of relative unacceptability of Arabic agentive passive sentences led them to transfer English agentive passive sentences into Arabic active sentences. They used 'passive void' strategies. Including "topicalization", they also used periphrastic structures and active voice. Although these students' percentages are not very high when compared with the previous strategy, the nature of the sentences plays a major role here.

Topicalization, as defined earlier, refers to the syntactic transformation that fronts the direct object or the indirect object to the sentence initial position; in Arabic, the topicalized object receives the nominative case. Students either maintained the by-phrase in Arabic but in active voice structures or used inflected verbs such as الذي كان سبيه / الذي أسستي. Such tendency in translation is acknowledged by many Arab researchers and linguistics and translation specialists: AlNajjar (2007:200), Aziz (1989:268), Farghal and Shunnaq (2011:123-124) and Shawqi (1991:50). Referring to Table 11 , topicalization strategy gained prominence in the third sentence that reflects a passive sentence where the subject of the active sentence is animate with $62 \%$ compared with almost $27 \%$ for maintaining passive strategy.

\subsubsection{Periphrastic Structure}

This is the second strategy used under the umbrella of a major strategy labeled "passive void" strategy along with topicalization and active voice. The influence of media is the main producer of periphrastic structure. Periphrastic transformation of English agentive passive is achieved by adding verbs like: تص/يتم/سيتم/قام/يقوم and changing the main English passive verb into a verbal noun (Al-Najjar, 2007: 182, Aziz, 1989: 268, Khalil, 2010:273 and Shabanah, 1981:295), as a result, topicalization is also achieved. Students may also maintain the by-phrase although the verb is active. 


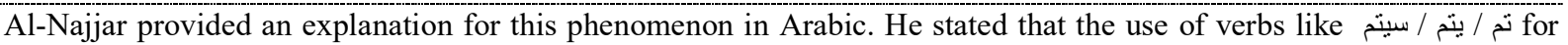
the past, present and future tenses is a sort of compensation to vocalic diacritics (al-Harakat: that (الضمة، الفتحة ، الكسرة ) are essential in Arabic passive formation. These marks are rarely used in the media, most books and in the media as well. Certain verbs like صَنَعَ : صنَنعَ، يَصنَع : : صنع ، يصنع could be read as active or passive if the diacritics are not used يُصنَع Referring to Table 1, periphrastic structure is not used that much when compared with other active verb strategies. These results also correspond to El-Haj Ahmad (2009) results that found about 5.00\% of students used this strategy. This could be attributed to the nature of verbs used in the translation test that sometimes oblige the translation of by-phrase into Arabic especially with the verb تن Accordingly, the product will be active verb and by-phrase at the same time. For example:

$$
\text { ـ الصندوق التربوي الذي تم تأسيسه من قبل وز ارة التربية والتعليم بدأ عمله يوم السبت . }
$$

\subsubsection{Activization}

Using this strategy, students make drastic changes to the sentence since they change the whole passive voice into active voice. The rationale behind this strategy is well established in literature. As stated above, many researchers believe that Arabic does not have agentive passive, although there are agentive passive sentences in the Glorious Quran, Hadith, and speech of the Arabs (Kalam al-Arab) where particles like من + الاسم and an an be used as a thanslation to the English by-phrase in a passive sentence (Khalil, 1993).

Some of them also state that the passive voice as a construction is not as common as active voice due to several reasons that are not limited to the complexity of passive constructions if all types of Arabic verbs are considered and the Arabic users' concern of the intelligibility and clarity of the delivered message. However, referring to Table 1, students did not use this strategy as some studies expected. These results correspond to El-Haj Ahmad (2009) results which showed that only $6.5 \%$ of students translated English agentive passive sentences into Arabic active sentences. This could be attributed either to students' literal translation in maintaining the agentive passive construction as in the first strategy or their choice to deliberately focus on the topic of the sentence (the object) by saving it in its initial position and then change the verb into active one as in the second and third strategies.

\subsubsection{Strategies related to the translation of English agentless passive into Arabic}

Considering studies conducted on English-Arabic syntactic contrastive analysis that take students into consideration, English agentless passive construction is translatable when compared with English agentive passive; (El Haj Ahmad, 2009, Khalil, 1993 and Mohawesh, 2004)) due to the existence of Arabic agentless passive. Although students primarily translated these passive sentences into Arabic passive, they also utilized other strategies.

\subsubsection{Maintaining Passive}

Using this strategy, students translated the English agentless passive into Arabic passive construction. Students used different Arabic agentless passive forms to correspond to English agentless passive. They either used passive verbs that are derived from Arabic perfect tense like in صُمدت, verbs that are derived from the Arabic imperfect tense like in تُحل, or they used passive participles that are derived from object nouns like in مصمة. Table 2 showed that relative high percentages were registered in this particular strategy especially in sentences 1 and 2, an idea that reflects students' ability in dealing with this type of passive when compared with English agentive passive. The low percentage in sentence number 5 reflects the type of passive used in this; "Managers ....expand when needed" that necessitates almost one acceptable translation: عند الحاجة / عندما تكون هناك حاجة

\subsubsection{Periphrastic Structure}

This strategy is achieved by adding words like تم / to the verb and changing that verb into a verbal noun (al-masdar). Examples are تم تصميم / يتم حل / تم تأسيس. Reasons for using this structure are similar to those reasons that are used in translating English agentive passive. The type of the verb in both cases (agentive and agentless) is the only criterion to decide on using the periphrastic structure. Table 2 showed that percentages of using this strategy were within the same range of those percentages used in translating agentive passive constructions. Finally, most researchers acknowledge the use of such construction in translation especially in media in both oral and written types.

\subsubsection{Lexicalization}

Using this strategy, students tend to either change the English passive verb into an Arabic active verb / verbal noun or they replace the whole passive verb with another contextually appropriate active verb. These processes are governed by the morphological, syntactic and semantic types of Arabic verbs, i.e. not all verbs are subjected to these processes. Examples are:

1. An ambitious campaign designed to raise awareness....

$$
\text { - حملة طموحة تهدف الى/ تسعى الى / تعمل على زيادة الوعي .... }
$$

2. Established in memory of her Majesty Queen Alia, Tkiyyat Um Ali is the first NGO...

$$
\begin{aligned}
& \text { 1. تأسست تكية ام علي احياء لذكرى وفاة الملكة علياء وهي اول منظمة غير حكومية في .......... }
\end{aligned}
$$

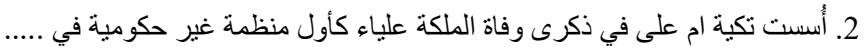

Unlike English, the verb "أسس", for example, is used in the first sentence as active while passive in the second sentence although in both cases, it is followed by the same noun phrase and the two translations are acceptable. Table 2 showed 
that lexicalization strategy gained high percentages in sentences one and five which makes it almost equal to maintaining passive strategy.

\subsubsection{Activization:}

Students tend to change the whole passive voice sentence into active voice and add the deleted expected agent. This strategy is not in harmony with language economy theory that promotes the use of appropriate numbers of words to deliver well-informed message (Coulmas, 2000). It also benefits from Arabic linguistic and contextual reasons that oblige the Arabic language user to use the Arabic passive . Shabanah (1981) and Shawqi (1991) reviewed purposes for using passive in Arabic which are the same reasons for not mentioning the doer of the action in an Arabic passive sentence. These purposes could be: (1) The doer of the action is not known, (2) The doer of the action is deleted deliberately, (3) The doer of the action is recoverable and (4) The doer of the action is deleted for stylistic purposes like conciseness. Table 2 showed that the percentages of this strategy were not high when compared with the first and third strategies. This could be attributed to the purposes of deleting the doer especially when they are not known. However, some students tend to compensate for the deleted elements when the doer of the action is recoverable. For example:

- Water shortage cannot be solved....

$$
\text { ـ لـ تسنطيع الحكومة حل مشكلة نقص المياه ..... }
$$

To sum up, students attempted the translation of English passive in general using two main strategies under which other strategies could be stated; "passive valid" strategies in the sense that they maintained the passive, and "passive void" strategies in the sense that they avoided using the passive. Considering the related literature, this study strategies are echoed -by sometimes using different terminology- in Farghal and Shorafat' study (1996) (cited in Massalha, 2005), in Khafaji's study (1996) and in Massalha's study (2005).

\subsection{Discussion of Findings related to the second question}

The second question is "What are Chesterman's syntactic strategies that correspond to the translation of the passive constructions strategies?" The current study strategies could be in harmony with the following Chesterman's syntactic strategies:

a. Maintaining passive strategy in agentive and agentless passive constructions could correspond

to Literal Translation strategy.

b. Periphrastic Structure strategy in passive constructions could correspond to Transposition.

c. Activization strategy (transferring into active voice) in agentive and agentless passive

constructions could correspond to Clause Structure Change strategy.

d. Topicalization strategy could correspond to Sentence Structure Change strategy

\section{Conclusion}

Generally, the findings of the study correspond to previous studies that there are various strategies utilized to translate the agentive and agentless passive into Arabic; however, it is noticeable that the tendency is moving towards emphasizing or even imposing the agentive passive on translation in particular and on Arabic in general. Percentages of maintaining passive strategy are exceptionally high among other strategies. The role of the media occupies the highest portion of influence on students' translations. The amount of their tacit knowledge upon which they decide on a certain strategy is exceptionally affected by their exposure to "oral language" and the written language of media. Finally and practically, the gap between theoretical knowledge of translation and its real practice is not that wide. Some participant students do have the potentials to take an effective part in their learning process and add self-discovered strategies to the existing list.

\section{References}

Al-Abed Al-Haq, F. and Ahmed, A. S.E.A. (1995).Comprehensibility: A Communicative Approach for the Evaluation of Translation. Turjman, 4(1), 61-83.

Alkhuli, M. A. (1999). Comparative Linguistics: English and Arabic. Amman: Dar Alfalah.

Al-Najjar, M. (2007). English Arabic Syntax for Translation. Amman: Atlas International Publishing.

Al-Raba'a, B. (2013). 'The Grammatical Influence of English on Arabic in the Passive Voice in Translation.' International Journal of Linguistics, 5(1), 204-218.

Aziz, Y. Y. (1989). A Contrastive Grammar of English and Arabic. Mosul: University of Mosul. Baker, M. (1992). In Other Words. London: Routledge.

Catford, J.C. (1974). A Linguistic Theory of Translation. London: Oxford University Press.

Chesterman, A. (2000). Memes of Translation: The Spread of Ideas in Translation Theory. Amsterdam: John Benjamin.

El Haj Ahmed, M.. (2009). Lexical, Cultural and Grammatical Translation Problems Encountered by Senior Palestinian EFL Learners at the Islamic University of Gaza, Palestine. Unpublished PhD Dissertation, University of Salford. Retrieved from http://usir.salford.ac.uk/15905/1/SPARC_2009.pdf on 13 April 2012. 
Farghal, M. and Shunnaq, A. (2011) Translation with Reference to English and Arabic: A Practical Guide. Irbid: Dar Al-Hilal for Translation.

Fisiak, J. (1981). Contrastive Linguistics and the Language Teacher. Oxford: Pergamon Press.

Hatim, B. and Mason, I. (1990). Discourse and the Translator. London: Longman.

James, C. (1980). Contrastive Analysis. London : Longman.

Khafaji, R. (1996). Arabic Translation Alternatives for the Passive in English. Papers and Studies in Contrastive Linguistics, 19-37.

Khalil, A. M. a. (1993). Arabic Translations of English Passive Sentences: Problems and Acceptability Judgments. Papers and Studies in Contrastive Linguistics, 17,169 b.(2010). A Contrastive Grammar of English and Arabic. Amman: Jordan Book Center.

Kirkwood, H.. (1966). Translation as a Basis for Contrastive Linguistic Analysis. International Review of Applied Linguistics in Language Teaching, 4(3), 175-182.

Kozáčiková, Z.. (2009). Chesterman's Translation Strategies in Syntax. In Theories in Practice: The Proceedings of the First International Conference on English and American Studies. Trušník, Roman and Nemčoková, K. (Eds.). Tomas Bata University in Zlín, Czech Republic.

Massalha, A. A. (2005). The Agentive Passive Construction in English and its Translation into Arabic. Unpublished M.A. Dissertation. University of Haifa.

Mohawsh, M. I. (2004). Problems of Translating the Passive Voice for Arab Learners of English and French. Unpublished M.A. Thesis. Irbid: Yarmouk University.

Nofal, K. H. (1993). The Use of Passive Voice in the Language of Journalism in Arabic and English. Unpublished M.A. Dissertation. University of Jordan.

Ryding, K. C. (2005). A Reference Grammar of Modern Standard Arabic. Cambridge: Cambridge University Press.

Shaheen, M. (1998). Theories of Translation and their Application to the Teaching of English/Arabic. Amman: Dar AlThaqafa Library for Publishing and Distributing.

Wright, W. (1986). A Grammar of the Arabic Language. Cambridge: Cambridge University Press.

Wong, L. (2006). Syntax and Translatability. Babel 52(2), 124-132.

$$
\begin{aligned}
& \text { المراجع العربية }
\end{aligned}
$$

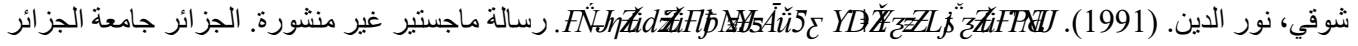

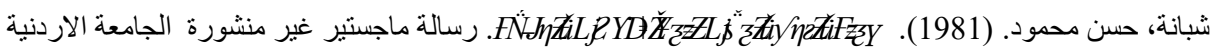

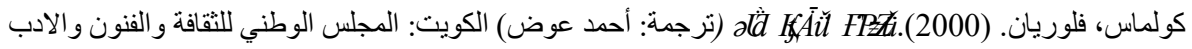

